\title{
Pygmalion to Galatea by Robert Graves: A Text and the Peripheries Thereof
}

\author{
By Bahaa-eddin M. Mazid ${ }^{*}$
}

\begin{abstract}
A change of a small word - "and" - in the title of one poem by the English poet, novelist, critic and classicist Robert Graves (1895-1985), Pygmalion and Galatea, into a smaller preposition - "to" - in a later poem by the same poet, Pygmalion to Galatea, results in a new text and a new relationship. The older poem is a narrative descriptive account of how Galatea turns from a statue, sculptured in imitation of Aphrodite, by a sculptor seeking perfection in a corrupt milieu, to a human and graciously submits herself to the desires of her creator, Pygmalion. At the core of the later poem is an address by Pygmalion to Galatea on how to become a perfect woman. The text of the poem is thus imbued by myth, art (both sculpture and poetry) and culture. The article analyzes the poem with a focus on the peripheries thereof, linking text to context and transtext, the verbal to the nonverbal, field to mode and tenor, syntax to lexis and pragmatics.
\end{abstract}

Keywords: Field, Metatext, Mode, Text, Tenor, Peripheries

\section{Text}

Pygmalion spoke and sang to Galatea

Who keeping to her pedestal in doubt

Of these new qualities, blood, bones and breath,

Nor yet relaxing her accustomed poise,

Her Parian rigour, though alive and burning,

Heard out his melody:

As you are woman, so be lovely:

Fine hair afloat and eyes irradiate,

Long crafty fingers, fearless carriage,

And body lissom, neither short nor tall.

So be lovely!

Ay you are lovely, so be merciful:

Yet must your mercy abstain from pity:

Prize your self-honour, leaving me with mine.

Love if you will; or stay stone-frozen.

So be merciful!

As you are merciful, so be constant:

I ask not you should mask your comeliness,

Yet keep our love aloof and strange,

Keep it from gluttonous eyes, from stairway gossip.

So be constant!

\footnotetext{
* Professor of Linguistics and Translation, Acting Dean, Faculty of Languages, Sohag University, Egypt.
} 
As you are constant, so be various:

Love comes to sloth without variety.

Within the limits of our fair-paved garden

Let fancy like a Proteus range and change. So be various!

As you are various, so be woman:

Graceful in going as well armed in doing.

Be witty, kind, enduring, unsubjected:

Without you I keep heavy house.

So be woman!

As you are woman, so be lovely:

As you are lovely, so be various,

Merciful as constant, constant as various.

So be mine, as I yours for ever.

(Poems 1914-1926, later omitted)

Then as the singing ceased and the lyre ceased,

Down stepped proud Galatea with a sigh.

Pygmalion, as you woke me from the stone,

So shall I you from bonds of sullen flesh.

Lovely I am, merciful I shall prove:

Woman I am, constant as various,

Not marble-hearted but your own true love.

Give me an equal kiss, as I kiss you.

\section{Aspects of Text and Discourse}

Not surprisingly, the territory was first staked out by a French literary theorist in the structuralist mode, Gérard Genette, whose Paratexts: Thresholds of Interpretation, published in 1987 and translated by Cambridge University Press into English in 1997, can lay claim to putting the term into the mouths of graduate students and tenure-trackers. Genette was drawn to the "accompanying productions" flitting around and inside a text, the stuff before, after, and in medias res that filters our perception of it. "Now the paratext is neither on the interior nor on the exterior: It is both; it is on the threshold; and it is on this very site that we must study it, because essentially, perhaps, its being depends upon its site" he decreed with characteristic Gallic clarity. That is, the paratext may look like an expendable spleen, but it is really a vital organ beating within-and without-the body of the text and providing essential life support. (Genette also delineated categories like peritext, epitext, hypertext, and hypotext, but best to take this one prefix at a time.)

Genette's own paratextual affinities were literary-framing devices such as epigraphs, forewords, and afterwords, or supplemental resources such as authorial correspondence, interviews, and diaries-but media scholars quickly latched on to 
his peripheral vision to zoom in on the infestation of spinoffs and sidebars proliferating in the new digital environment (Doherry 2014).

Metatext is text about text, as opposed to text about the world - the classic suppositio materialis as opposed to suppositio formalis, or metalanguage as opposed to object language. Metadiscourse can be defined in the same vein in relation to discourse. It is easy to get lost in the attempt to distinguish text from discourse, though. Some tolerance of oversimplification is needed to find a way out. Here is a college teacher's solution of the issue, substantially adapted: Text, e.g., the print book of Wuthering Heights, is a "behavioral non-interactive event" limited to a reader's understanding of its characteristics and its meaning. Discourse, on the other hand, is a "social, interactive event" with many layers of communication - in the case of the novel: novelist-reader, novelist-character, reader-character, character-character - and many layers of purpose - narration, meta-narration, description, dialogue, etc. (Karen Hardison 2011, goo.gl/Da3g TY).

"Text is transportable, but discourse is not", Haberland (1999) argues. "Text is transportable not only in space but also in time; it makes tradition possible. Discourse vanishes the moment it has happened; it can be recalled, but not called back. Text can be reused, consumed repeatedly. As a corollary, text can be analysed, but discourse cannot. In conversation analysis, the data is the discourse, not the transcript (which is a text)". Text, Haberland adds, is "frozen" discourse. Discourse is an event that has "only one here and now". The relationship to "a here and now ... is originally only defined for discourse" (1999: 914). Mey (1993: 187) puts it slightly differently: "Discourse is what makes the text context-bound, in the widest sense of the term".

Metatext and metadiscourse can be and have frequently been used interchangeably, but the former has often shown up in literary studies, while the latter has often been investigated in spoken and classroom discourse analysis and in academic writing. Hardly, if at all, has the term metadiscourse been used to mean "discourse that replaces discourse". This is an integral aspect of the term metatext used in the context of the present study. A translation may be defined as "a text in one language that represents or stands for a text in another language" (Palumbo 2009: 122, italics added). The relationship between a text and its translation is intertextual.

Gerard Genette proposed the term "transtextuality" as a more inclusive term than "intertextuality" (Genette 1987). He listed five subtypes of transtextuality:

- intertextuality: quotation, plagiarism, allusion - some parts of which are obligatory, including generic requirements such as meter and rhyme in traditional poetry;

- paratextuality: the relation between a text and its "paratext" - that which surrounds the main body of the text - such as titles, headings, prefaces, epigraphs, dedications, acknowledgements, footnotes, illustrations, dust jackets, etc. - subdivision: epitetext (outside a bound volume or book) and peritext (inside the confines of a bound volume or book); 
- architextuality: designation of a text as part of a genre or genres (Genette refers to designation by the text itself, but this could also be applied to its framing by readers);

- metatextuality: explicit or implicit critical commentary of one text on another text (metatextuality can be hard to distinguish from the following category);

- hypotextuality (Genette's term was hypertextuality): the relation between a text and a preceding "hypotext" - a text or genre on which it is based but which it transforms, modifies, elaborates or extends (including parody, spoof, sequel, translation).

A poem is an intertext, and Pygmalion to Galatea by Robert Graves (1926) is no exception. The very title of the poem links it not only to Greek mythology, but also to the bulk of adaptations of the Pygmalion myth, as well as some other poems by the same poet, most notably his Pygmalion and Galatea and Love in Barrenness. Pygmalion to Galatea is a poem about a creator-creature relationship where the creator - Pygmalion - provides Galatea - his creation with a manual for being a perfect woman, describing the qualities he wants her to possess.

The poem is intertextually related to the many accounts of the story, including one by Graves himself in his The Greek Myths. Pygmalion fell in love with Cyprian Aphrodite, but she of course rejected his advances, "she would not lie with him", whereupon in order to assuage his longing he created the flawless sculpture of a woman. Some say he made a sculpture of Aphrodite herself. Then, Pygmalion laid the statue beside himself in his bed, and fervently prayed to the Goddess. She took pity on him, and brought the sculpture to life - as Galatea (Theinkbrain 2011). The myth, thus, is not the beginning of the intertextual chain. The chain begins with an unrequited love Pygmalion's of Aphrodite - and a rendering of the beloved into a statue Galatea (which means there is a visual intertextual relation between the image of Aphrodite and the statue of Galatea). The poem is also linked to the visual representations of Pygmalion addressing Galatea. The poem and the image below can be seen as an inter-semiotic translation of each other (Figure 1).

Figure 1. Pygmalion to Galatea - A Visual Representation

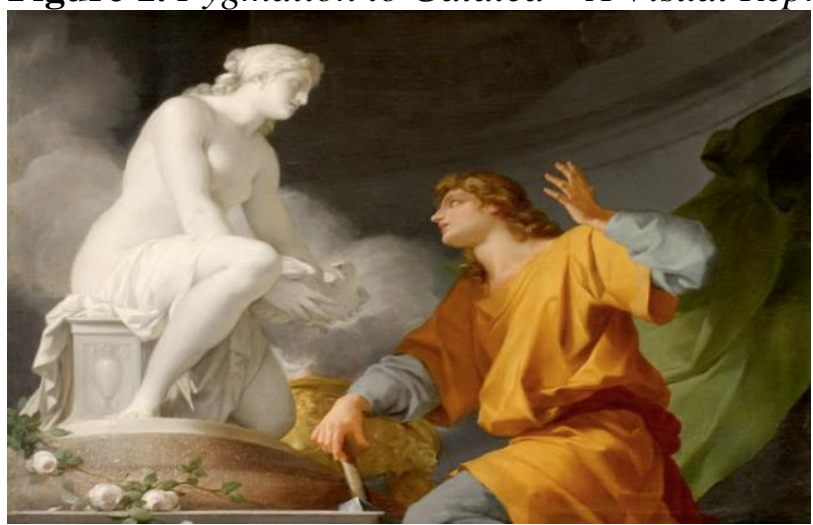

Source: goo.gl/Ev4PBB. 
The mythical story luckily coincides with a life experience Graves had with Laura Riding, while still married to Nancy Beryl. Graves first knew Riding on paper, admired her poetry, corresponded with her and wanted to meet her personally. He "woke her from the page and invited her into his life" seeking her "female love" as well as her "intellectual partnership" (O’Prey 1993: 237). Thus, O'Prey regards Pygmalion to Galatea as a poem of harmony and equal love. It was a release from the confusions caused by the WWI and a harmonious counterpart to the "lustful imagination" in earlier poems by Graves. (O'Prey's thesis itself is a metatext on the poetry of Robert Graves written between 1914 and 1946. Another metatext on the poem is the article by Simon Brittan (1999) where the relation of harmonious equal love is replaced by a relation of control and jealousy).

A real life story - some details in the life of Robert Graves - and a myth result in a poem. The real life story is defamiliarized into a poetic experience through a revival of the myth. The diagram of narrative communication (Phelan 2014: 52) can be applied to capture some aspects of the poem as context and intertext (Figure 2).

Figure 2. Pygmalion to Galatea - Aspects of Text and Context (1)

\begin{tabular}{|c|c|c|}
\hline Implied Author & Resources & Actual Audience \\
\hline $\begin{array}{l}\text { Outside the text; in } \\
\text { history; occasion of } \\
\text { writing - Graves, } \\
\text { Riding and other } \\
\text { aspects of real life that } \\
\text { pertain to the text. }\end{array}$ & $\begin{array}{l}\text { Character - teller and listener; } \\
\text { Voice - speaker, tone, values; } \\
\text { Structure. Pygmalion and Galatea, } \\
\text { speaking and responding. What } \\
\text { Pygmalion values as the qualities } \\
\text { of a perfect woman. }\end{array}$ & $\begin{array}{l}\text { Rhetorical readers; in } \\
\text { history, occasion of } \\
\text { reading - Story, Myth } \\
\text { and Poem. }\end{array}$ \\
\hline
\end{tabular}

Although the story of Graves and Riding can serve as a background to the poem, it cannot be cited as its single motive. A rhetorical reader may feel free to read it as a retelling of the myth of Pygmalion and Galatea, an allegory for Riding and Graves, or as a general recipe for women on how to be perfect. The two circles in the diagram below locate the mythical characters of Pygmalion and Galatea in their mythological context and the two characters of Graves and Riding in their Victorian context. 
Figure 3. Pygmalion to Galatea - Aspects of Text and Context (2)

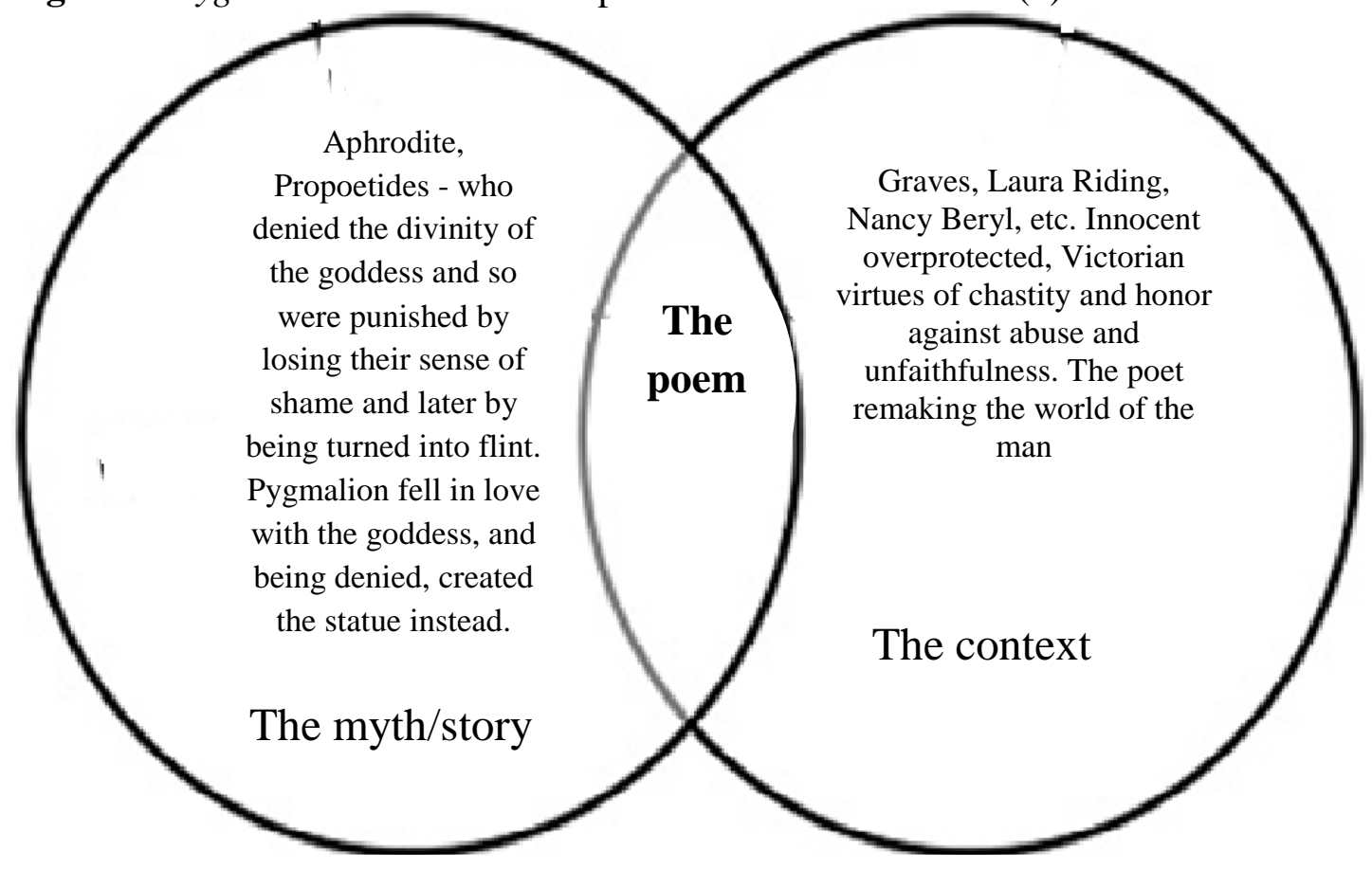

The poem touches on both contexts - the context of the original myth and the context where and when Robert Graves wrote it (Figure 3).

\section{Field, Tenor and Mode}

Field: the social action - "what is actually taking place" - refers to what is happening, the nature of the social action that is taking place and what is it that the participants are engaged in (Martin 1992: 499). The field of a discourse or a text is, put more simply, its subject matter, its topic or topics, its theme.

Tenor: the role structure - "who is taking part" - refers to participants, the nature of the participants, their statuses and roles: what kinds of role relationship between the participants, including permanent and temporary relationships, both the types of speech role that they are taking on in the dialogue and the whole cluster of significant relationships in which they are involved (Martin 1992: 499-500).

Mode: the symbolic organization - "what role language is playing" - refers to what part language is playing, what is it that the participants are expecting the language to do for them in the situation: the symbolic organization of the text, the status that it has, and its function in the context, including the channel (is it spoken or written or some combination of the two?) and also the rhetorical mode, what is being achieved by the text in terms of such categories as persuasive, expository, didactic, and the like (Martin 1992: 500). 
The first stanza is - in Genette's narratology model - a paratext. It introduces Pygmalion's speech to Galatea. The first line - "Pygmalion spoke and sang to Galatea" - contains two parts of the discourse triangle: the speaker and the listener, the addresser and the addressee, and describes the utterances to follow as speech and song, or melody, at the same time. The description of the locutions to follow as "song" and "melody" is likely to soften their imperative force. A song or a melody is spoken, but the readers - the actual audience receive it in the medium of writing. The first-order speaking subject - the poet - is not identical with the second-order speaker, except in the first stanza and the first two lines in the last stanza where Galatea responds to Pygmalion's "song". The poet introduces the speech by Pygmalion and the response by Galatea. The two authorial interventions allow the bracketing of Pygmalion's and Galatea's locutions as direct speech, as well as the transfer of the interaction to later readers.

The first stanza also describes the situation or the context where Pygmalion's speech to Galatea is delivered. Galatea, a "transient" being, is still on her platform, not yet "relaxing her accustomed poise", her "Parian rigour" ("Parian" comes from Paros, the Greek island renowned for its fine-textured, white Parian marble, used since antiquity for sculpture). Yet, she is "alive and burning", with qualities quite new to her, qualities of "blood, bones, and breath". She is in between, in doubt, no longer a sculpture, but not a woman yet.

The bulk of the poem is a set of instructions delivered by Pygmalion to Galatea on how to be a perfect woman. Because Galatea is not a human yet and because Pygmalion is her maker, he seems to have the felicity conditions to command her. In the sense that the poem involves a teacher-(non-human) learner relationship - Pygmalion, the creator of the statue, is providing it with a manual for being a perfect human - it is a didactic poem. In most of the poem, then, the teaching is done through language, song or melody, which means that, in Systemic Functional terms, it is a Verbal Process.

Pygmalion is a Sayer and his Verbiage is the set of commands he delivers. Galatea is the Target of the Process, hence the paratextual title phrase "Pygmalion [speaks, speaking, -'s speech] to Galatea". In the last stanza, there is a role reversal. Galatea becomes the Sayer; her Verbiage is the set of promises she gives Pygmalion, now the Target, and her request that he kiss her back as she kisses him. She will return his favor - waking her from stone - and follow his instructions, more like an equal now, than a silent statue - "Give me an equal kiss, as I kiss you".

In each case, the Verbal Process is introduced with a narrative by the poet - "Pygmalion spoke and sang to Galatea/Who ... Heard out his melody" and "Then as the singing ceased and the lyre ceased/Down stepped proud Galatea with a sigh".

The series of instructions in the poem starts with a conventional focus on physical beauty (unfortunately, a female is first identified with how she looks), followed by other demands so "stringent" that they would suit Galatea the statue, rather than the woman. There is an echo of another poem by Graves Love in Barrenness: "poised in marble flight you stood". A balance between strength and softness is invited. The last line closes the stanza with an emphasis 
on Pygmalion's vision as ideal. The first "lovely" is open-ended, but the word in the last line is conditioned by Pygmalion's rules for being lovely - "be lovely" the way I have described, the way I want you (Brittan 1999: 88).

The next stanza centers on the adjective "merciful". Asking Galatea to be merciful, but not pitiful, suggests that Pygmalion feels more inferior, less perfect, and thus likely to err and seek mercy and forgiveness. Being merciful may also involve acceptance of sexual suffering without protest. The choice offered between loving and being stone-frozen suggests that it is love that distinguishes a human from a piece of stone. The stanza closes the same way the previous one does, with a repetition of the imperative to underscore the condition that it is Pygmalion's idea of being merciful Galatea has to abide by.

The next quality Pygmalion seeks in his creation is being constant and keeping their love aloof and strange from gluttonous eyes and gossip. The adjective "constant" also involves being faithful. Pygmalion seems to be aware that with beauty and mercy Galatea will certainly stir love and desire from other males and he is already jealous about that.

Galatea, moreover, should be various, notwithstanding constancy and fidelity. Variety is the spice of life - and of love as well. "Let fancy like a Proteus range and change" is an invitation bound both by the limits referred to above, the limits of a private relationship between two, and by the very reference to Proteus. Proteus was defeated and turned to stone by Perseus. The ranging and changing Galatea is allowed by her creator and thought of as essential to an everlasting love are confined (Brittan 1999).

The attributes required by Pygmalion are his conditions for being a perfect woman - graceful, armed, witty, kind, enduring and subjected. The last attribute sounds very strange given the series of commands and requirements Galatea has to follow and uphold. Yet, that is what Pygmalion needs Galatea to be in order to be able to help him maintain his house. Being a perfect woman seems to be equated with being able to maintain a family.

The qualities of a perfect woman are reiterated in the next stanza in a manner that suggests they are all equally important and indispensible. The culmination of all requirements and conditions is that Galatea must be Pygmalion's or else remain a statue - a choice as narrow as "love or stay stonefrozen" already offered by the loving sculptor. The selfishness of "be mine" is softened by Pygmalion's pledge to be "hers" forever.

An authorial intervention follows, separating Pygmalion's instructions from Galatea's response. The bulk of instructions is still referred to as "singing". Grateful to her creator who woke her "from the stone", Galatea responds positively to Pygmalion's commands, promises to wake him "from the bonds of sullen flesh" and makes her only command at the end of the poem - "Give me an equal kiss, as I kiss you". Rather than promising to fulfill the desires of his flesh, she promises to release him from them. 


\section{Syntax, Lexis and Pragmatics}

The predominant structural pattern in the poem is the imperative form, with the verb be followed by an adjective in each case. The imperative form is relevant here, where a human talks to a statue. Interrogatives and statements can trigger an interaction, which is not likely in this speech situation. When Galatea steps down and speaks like a human, she responds with Commissives "So shall I you from bonds of sullen flesh", "Lovely, I am merciful, I shall prove. Woman I am, constant, as various, Not marble-hearted, but your own true love" - and an Imperative - "Give me an equal kiss, as I kiss you".

Except for the first and the last, each stanza begins with the pattern "As you are $\mathrm{X}$ so be $\mathrm{Y}$ " and closes with "So be $\mathrm{Y}$ ". The implicit subject in the imperative structures is always "you" referring to Galatea and the underlying structure is "I ask/order you to be Y", with "I" referring to the first order speaker - Pygmalion. The $\mathrm{Y}$ slot is filled up with the following adjectives respectively: "lovely", "merciful", "constant", and "various". These adjectives cover almost all aspects of personality - appearance, emotion, temperament, as well as behavior. "As" can mean "because", which is very likely because of the addition of "so", and can mean "while" - while you are transformed from a statue into a woman. The structure suggests that, for Pygmalion, a perfect woman is, by definition, lovely, merciful, constant and various.

Because there are no Material Processes - action and movement - in the poem, most of the strength thereof lies in the use of adjectives: "... turn where you will in poetry, the phrases and lines selected as of poetic value achieve their quality through the distinctive use of verb and adjective" (Fairchild 1916: 311). Adjectives "breathe life" into nouns. "Adjectives ... are powerful. They are the difference between a car and a fast car. They are the difference between a man and a rich man, or tall man, or annoying man. Adjectives help us better explain and understand the world. Our language would be pretty boring without them" (goo.gl/tmor9T). The meanings of the four main adjectives in the poem point both inward and outward, qualities that Galatea would possess and would, meanwhile, have an impact on the world surrounding her.

- lovely: beautiful, attractive, pleasant; inspiring love/affection; (archaic); full of love; (obsolete) loving.

- constant: loyal, faithful, unchanging, regular, persistent.

- merciful: full of mercy; compassionate; (with royalty) gracious;

- various: displaying variety; many-sided: variegated; inconstant (www.thefreedictionary.com)

It is hard, to say the least, for a single woman to possess all these attributes, some of which are quite contradictory, at one and the same time, and maintain them for long. The difficulty is resolved and softened when the requirement of being "various" is confined to the couple's garden - "Within the limits of our fairpaved garden". Pygmalion is in fact asking Galatea to be constant with strangers, but various at home - a condition almost every man expects his spouse to fulfill, at least in communities where "[in] popular advice literature and domestic novels, as 
well as in the advertisement columns of magazines and newspapers, domesticity was trumpeted as a female domain" (italics added, goo.gl/HT1XFt).

The accepted reasoning was that the career for women was marriage. To get ready for courtship and marriage a girl was groomed like a racehorse. In addition to being able to sing, play an instrument and speak a little French or Italian, the qualities a young Victorian gentlewoman needed, were to be innocent, virtuous, biddable, dutiful and be ignorant of intellectual opinion.

Whether married or single all Victorian women were expected to be weak and helpless, a fragile delicate flower incapable of making decisions beyond selecting the menu and ensuring her many children were taught moral values. A gentlewoman ensured that the home was a place of comfort for her husband and family from the stresses of Industrial Britain.

A woman's prime use was to bear a large family and maintain a smooth family atmosphere where a man need not bother himself about domestic matters. He assumed his house would run smoothly so he could get on with making money (goo.gl/7CgI12).

The perfect auxiliary imperative is often used to influence recipient's behavior, to get the addressee to carry out an act. Categorically, an imperative is a threat to negative face - a limitation on the addressee's freedom of action. Thus, an educational website warns learners of English of carelessly using an imperative: Imperatives should be used carefully in English; to give firm orders or commands, but not as much when trying to be polite or show respect to the other person, e.g., Give me that tape, please (goo.gl/4KKH72). However, the grammatical imperative form and the directive speech act should be separated. Not every imperative in form is a directive in function.

In the poem, the series of commands are meant to shape not only Galatea's conduct, but also her character. The adjectives used in the poem are elaborated so that there is no doubt about what Pygmalion wants them to mean. The commands are reinforced through the use of a variety of anadiplosis - the repetition of the last word of one phrase, clause, or sentence at or very near the beginning of the next. The second stanza closes with "So be lovely"; the next opens with "As you are lovely, so be merciful". This pattern is repeated throughout the four stanzas where Pygmalion instructs Galatea.

In the last stanza, the verb "stepped" and the adverbial of place "down" are fronted and Galatea is described as "proud":

Then as the singing ceased and the lyre ceased,

Down stepped proud Galatea with a sigh.

"Pygmalion, as you woke me from the stone,

So shall I you from bonds of sullen flesh.

Lovely I am, merciful I shall prove:

Woman I am, constant as various,

Not marble-hearted but your own true love.

Give me an equal kiss, as I kiss you." 
The contradiction between "proud" and "stepped down" and the sigh she descends with reveal reluctance and lack of enthusiasm. She does not seem very happy with her compliance. However, she agrees. She has already kept Pygmalion's conditions of being a perfect woman by heart. She is polite in the sense of Leech's Politeness Principle, Maxim of Agreement. She counters her creator's limited choice of loving or being stone-frozen with the promise not to be marble-hearted and his request that she be "his" with "your own true love". This is a perfect ending, albeit troubled with the challenging request in the imperative "Give me an equal kiss", underlining the need for reciprocity and mutuality in love.

\section{Non-Verbal}

The poem closes with Galatea requesting a kiss back as she kisses Pygmalion. A kiss is an instance of non-verbal communication, specifically of haptics (touching). Galatea's "as I kiss you" suggests that it is a mutual lip kiss, the most direct form of non-verbal communication, second only to intercourse and foreplay in expressing intimacy and affection, love and passion.

In the same stanza, we can behold Galatea "stepping down" and hear her "sigh". A sigh is a paralinguistic, quasi-lexical, semi-conscious signal that can indicate a yielding attitude. A sigh typically reveals a negative mood, e.g., disappointment, frustration, defeat, ennui, or wistfulness. It can also be interpreted as a sigh of relief from the bondages of stone. Taking a long breath inhale followed by a sigh can signal getting ready for a tough task and a long run - the task of becoming a human in the strict manner stipulated by her creator. This is not all the nonverbal communication the poem contains.

At the outset, Galatea is no longer a statue - "alive and burning" - but not a human yet - still rigorous, "not yet relaxing her accustomed poise", still "keeping to her pedestal in doubt". In this transient state, Pygmalion spoke and she could hear his melody. The delineation of being lovely in the second stanza is achieved largely through a description of appearance and body language "fine hair afloat" and "eyes irradiate", "long crafty fingers", "fearless carriage", and a thin, supple, graceful body, "neither short nor tall".

Talking about loveliness is where non-verbal communication comes in handy. The other qualities may involve some non-verbal signals - "or stay stone-frozen", which refers inside as well as outside; "I ask not you should mask your comeliness", "keep it from gluttonous eyes and stairway gossip", which have to do with abstaining from public display of attractiveness as well as of her love, and confining both to the "limits of our fair-paved garden."

Nonverbal communication signals, frequently a periphery of verbal communication, function to reinforce the meanings of the text. It is, however, difficult to reconcile the imperative mode that dominates the text with the popular visual representations of a Pygmalion kneeling in front of Galatea's statue. One way out is to find this partial reconciliation in the metalinguistic descriptions of Pygmalion's articulations as a melody, a song. 


\section{Interpretation and Conclusion}

It is very likely that the story retold by Graves echoes his own story with Laura Riding, as already suggested. It is also very likely that it is a poem about art and its relation to an artist. Galatea is after all a statue shaped by Pygmalion, a joint creation of human art and divine spirit. A work of art is shaped by an artist, but once it is released, the artist ceases to have control over it.

Galatea's compliance with Pygmalion's delimiting conditions is quite normal for a statue. There is no reason why she should be expected to remain as obedient when she is a full-fledged human being. The first thing she does after promising to respect her creator's imperatives is kiss him and ask for an equal kiss back the same time. Such is the relationship between an artist and a piece of art, verbal or visual. The artist can shape his/her piece the way s/he likes; once it is exposed, $\mathrm{s} /$ he ceases to have control on how it affects its recipients.

The tension between art, myth and life is depicted in the poem through an interplay between current text and prior text and myth on the one hand, and the world, the Victorian world of Robert Graves, on the other, and between authorial narrative statements and direct speech by the characters. There is an irony, it has already been suggested, at the heart of the poem and in the tension between art and life: the relation between "desire, intention and result" (Brittan 1999: 91).

In a "world of disjunction and difference", some things "mirror each other". The self "makes up the text" and teaches readers how to read it (Garber 1988: 212). At least three discourse worlds are created in three contexts - the discourse of the myth, the Victorian discourse and the discourse of potential readers. In addition to (intertextually) echoing the famous myth and the poet's prosaic account thereof, the poem partially (and intersemiotically) mirrors portraits of Pygmalion adoring Galatea, the statue, but verbally subverts those portraits by reversing roles, whereupon Pygmalion takes on the role of a teacher. In the last stanza, a periphery (a peritext) of Pygmalion's series of commands, Galatea responds to her creator, promising compliance and seeking reciprocity, and thus subverts the teacher role assumed by the sculptor.

In the initial periphery (peritext) of the poem, in the first stanza, the first alternative world is suggested, an indication that this is a recounting of a myth, not a record of historical events, although it echoes some (extratextual) parts of the poet's life - the second discourse world in the poem. The poem's discourse worlds create a continuity of experience from the mythical to the poetic to the real. On the other hand, the peripheries of the text, those surrounding Pygmalion's and Galatea's utterances inside the poem and those external elements being echoed thereby reinforce and occasionally subvert the whole interaction between the creator and his creation. Reinforcement leads up to an interpretation where the relation between the two personae is one of creation and control, while subversion leads up to an interpretation where equality and reciprocity are inevitable outcomes of the interaction. 


\section{References}

Brittan S (1999) Graves and the mythology of desire. In PJ Quinn (Eds.), New Perspectives on Robert Graves (pp. 84-93). London, New Jersey and Ontario: Associated University Presses.

Doherry T (2014, Jan. 6) The paratext's the things. The Chronicle of Higher Education. Available from goo.gl/B4xbJY. [Accessed: 6 January 2016].

Fairchild AHR (1916) The verb and the adjective in poetry. The English Journal 6(5): 310-319.

Garber F (1988) Self, Text and Romantic Irony: The Example of Byron. New Jersey: Princeton University Press.

Genette G (1987). Seuils. Paris: Le Seuil.

Haberland H (1999) Text, discourse, discours: The latest report from the Terminology Vice Squad. Journal of Pragmatics 31(7): 911-918.

Martin JR (1992) English Text: System and Structure. Amsterdam: Benjamins.

Mey JL (1993) Pragmatics: An introduction. Oxford: Blackwell.

O'Prey P (1993) The Poetry of Robert Graves 1914-1946. Unpublished Ph.D. Thesis. Department of English, Faculty of Arts, University of Bristol, UK.

Palumbo G (2009) Key Terms in Translation Studies. London: Continuum.

Phelan J (2014) Voice, tone and the rhetoric of narrative communication. Language and Literature 23: 49-60.

Theinkbrain (2011) Two poems by Robert Graves: "Pygmalion to Galatea" and "Galatea and Pygmalion". Retrieved from goo.gl/tJ3QWY. [Accessed: July 26, 2016] 
